\title{
Bridging the Gap between Theory and Practice: An Analysis of Mzuzu University's Bachelor of Education (Language) Programme
}

\author{
Lydia Kishindo-Mafuta \\ Private Bag 201, Department of Teaching, Learning and Curriculum Studies, Faculty of Education, Mzuzu University, Mzuzu, \\ Malawi \\ Email: lydiakishindo@yahoo.com
}

How to cite this paper: Kishindo-Mafuta, L. (2021). Bridging the Gap between Theory and Practice: An Analysis of Mzuzu University's Bachelor of Education (Language) Programme. Open Journal of Social Sciences, 9, 167-181.

https://doi.org/10.4236/jss.2021.911014

Received: July 30, 2021

Accepted: November 22, 2021

Published: November 25, 2021

Copyright () 2021 by author(s) and Scientific Research Publishing Inc. This work is licensed under the Creative Commons Attribution International License (CC BY 4.0).

http://creativecommons.org/licenses/by/4.0/

\begin{abstract}
Language teacher education should provide student teachers with pedagogical content knowledge which is the knowledge that separates a teacher from a mere major of English. PCK means a student teacher will have knowledge of the content, the pedagogy as well as the context in which this will be used. This means the process of one acquiring PCK ensures that there is a link between theory and practice. This study therefore aimed at analysing the Bachelor of Education (Language) programme at Mzuzu University in order to understand how theory and practice are integrated. The data was generated through document analysis. The study has revealed that the programme has made an effort to integrate theory with practice through the kind of courses that are offered to the students. The English teaching methodology courses provide a platform in which the content is integrated into the practice. In addition, the theoretical knowledge gained in the lecture rooms is actualised through teaching practice.
\end{abstract}

\section{Keywords}

Pedagogy, Content, Teaching Methods, Education Foundations

\section{Introduction}

Mzuzu University is an institution of higher learning situated in the Northern Region of Malawi. The institution is a public university which was established in 1997 by the act of parliament. It started with one faculty, the Faculty of Education whose aim was to train secondary school teachers in order to address the need for qualified teachers in Malawian schools. Amongst the many teachers 
that the Faculty of Education produces, it produces teachers of Language; English, French and Chichewa.

One of the programmes that the faculty offers is Bachelor of Education (Language). According to the Bachelor of Education (Language) Curriculum Document (2016), the Bachelor of Education (Language) programme is intended to address human resource needs, not only in the teaching fraternity but also in all fields that demand linguistic potential and orientation. The Bachelor of Education (Language) programme aims to produce teachers of English, Chichewa and French. The graduate of the programme is expected to be a specialist in specific language(s) to enable him/her to operate in diverse contexts. The product will also be capable of handling language at various levels of complexities and use it as deemed appropriate. The current study will focus much on specialists of English as a second language. Mzuzu University has been producing teachers of English since 1999 but no study has been done to understand how theory and practice are integrated into the curriculum.

Loewenberg Ball (2000) and Darling-Hammond (2006) argues that one of the perennial dilemmas of teacher education is how to integrate theoretically based knowledge that has traditionally been taught in university classrooms with the experience-based knowledge that has traditionally been located in the practice of teachers and the realities of classroom and schools. This could be true as experience has shown that the student teachers that we send for teaching practice seem to be confused the moment they get into the classroom to teach. The confusion is not because they did not learn but because they cannot apply what they learnt into practice.

A second language teacher education programme therefore, should provide student-teachers with the content of the subject that they are going to teach; the pedagogies that they will need to use to transmit that content to the learners; and it should help them to learn how to teach (learn to use the knowledge in practice) (Loewenberg Ball, 2000; Darling-Hammond, 2006; Richards, 2008; Johnson, 2009). However, the challenge is in integration of the theoretical knowledge and the practice of teaching. This study therefore was aimed at analysing the Bachelor of Education (Language) programme at Mzuzu University in order to understand how theory and practice are integrated.

\section{Literature Review}

\subsection{Second Language Teacher Education}

Loewenberg Ball (2000), Graves (2009), Johnson (2009), Richards (2008), and Darling-Hammond (2006) explain that a second language teacher education programme informs three broad areas. Firstly, the content of the second language (L2), secondly the pedagogies of how L2 is taught and finally how teachers learn how to teach.

Graves (2009) argues that the role of teacher education programme in the 1970s was to transmit two-part knowledge base, that is, knowledge about lan- 
guage, learning theories, the target culture and knowledge about methodologies and training teachers to use skills. This seems to agree with Richards's (2008) observation that there have traditionally been two strands of knowledge base within the field of SLTE. That is, one focusing on classroom teaching skills and pedagogic issues and the other focusing on what has been perceived as the academic underpinning of classroom skills; namely, knowledge about language and language learning. Most of the teacher education programmes in Malawi, in the absence of a thorough evaluation, seem to have the kind of knowledge base Richards has highlighted, as the programmes offer courses in Pure and Applied Linguistics, Methodology courses and Education Foundations courses.

Freeman (2009) claims that the teacher education programs differed for those learning to teach foreign languages or languages other than the English language and those learning to teach English as a Second Language or English as a foreign language. For, those training to teach other languages, their training included language, literature, cultural studies with some attention to classroom teaching (Schulz, 2000). On the other hand, those training to teach English learnt about language content through grammar and applied linguistics; about learning through the study of second language acquisition; and about teaching itself through the study of classroom methodologies. Freeman's historical background still emphasizes on the two strands of knowledge base, the content knowledge through SLA and the pedagogical knowledge.

The knowledge base of L2 teacher education has assumed that the disciplinary knowledge that defines what language is, how it is used, and how it is acquired that has emerged out of the disciplines of theoretical and applied linguistics is the same knowledge that teachers use to teach the L2 and that in turn, is the same knowledge that students need in order to learn (Johnson, 2009). This argument seems to be in agreement with Darling-Hammond (2006) who argues that the dilemma that the teacher education programs find themselves in is that many lay people and a large share of policymakers hold the view that almost anyone can teach reasonably well. According to Darling-Hammond, it is argued that entering teaching requires, at most, knowing something about the subject, both in proficiency in the language and knowledge about its structure (Graves, 2009) and the rest of the fairly simple "tricks of the trade" can be picked up on the job.

Contrary to the views cited by Darling-Hammond (2006), Johnson (2009) and Graves (2009), Richards (2008) argues that teaching is not simply the application of knowledge and of learned skills. It is rather "a much more complex cognitively driven process affected by the classroom context, the teacher's general and specific instructional goals, the learner's motivations and reactions to the lesson, the teachers' management of critical moments during a lesson" (p. 167). In other words, teaching of a language requires more than knowledge of the subject matter, it also requires knowledge on how this subject matter can be transferred to the learners. In view of this, the knowledge base of L2 teacher education must 
include not only disciplinary or subject knowledge that defines how language is structured, used and acquired but must also account for the context of L2 teaching, that is, what and how language is actually taught in L2 classroom as well as teachers and students' perception of that content (Freeman \& Johnson, 1998 as cited in Johnson, 2009).

\subsection{Knowledge about Language and Second Language Teacher Education}

As much as the focus of SLTE content has shifted from what the teachers should know to the understanding of who the teachers are; what skills they have; and who their learners are; the knowledge about the language cannot be ignored as part of the knowledge base for SLTE. Wright (2002) argues that "becoming a language teacher involves a number of related processes, in particular, learning to create connections between the linguistics, or 'content' and the methodology or 'teaching', aspects of language teaching" (p. 113). In addition to Wright's (2002) argument, Bartels (2005) argues that to enable language teachers to take full advantage of Knowledge about Language (KAL) in their teaching, a significant amount of time in Applied Linguistics classes needs to be invested in helping novice teachers develop and engage in a variety of deliberate practice activities.

Related to the Knowledge about Language is Teacher Language Awareness. Andrews (2007) citing Thornbury (1997) defines Teacher Language Awareness (TLA) as the knowledge that teachers have of the underlying systems of the language that enables them to teach effectively. According to Wright (2002), a linguistically aware teacher does not only understand how language works, but also understands the students' struggle with language and is sensitive to errors and other inter-language features. It is apparent from these discourses that the knowledge about language goes beyond just knowing the structure of the language, it is more to do with how the language is acquired, learnt, used, interpreted and taught. Wright (2002), Bartels (2005) and Andrews (2007) agree on the need for the teacher of second language to have some knowledge of the language that they will teach.

According to Attardo and Brown (2005), teachers of language need to have some idea about issues of prescriptive and descriptive grammars, language use and variation, language structure and history of English. They further argue that the teachers may not teach these aspects as part of the content but they will use them as background in making educational decisions while teaching reading, writing and oral communication. Andrews $(2001,2003)$ conversely argues that the L2 teacher needs to have knowledge about language and knowledge of that language. He looks at the knowledge about language as the subject matter knowledge which is the grammar of the language, and the knowledge of language as the proficiency in the language or the communicative language ability (CLA). Beytekin and Chipala (2015) likewise emphasise the importance of linguistic 
courses and contend that course work in the specific academic content area, a teacher is assigned to teach can promote teacher quality and student achievement in some subject and grade levels.

KAL and TLA indicate the importance of a teacher having content knowledge. Suffice to say that knowing who your learners are and having the skills to impart knowledge may not be enough for a teacher. The teacher needs to have knowledge of the subject content he or she is going to teach. Therefore, a course in linguistics may be very important in LTE. Bartels (2005) also argues that "armed with knowledge about the language, teachers will among other things, be able to understand and diagnose student problems better, provide better explanations and representations for aspects of language and have a clearer idea of what they are teaching" (p. 205).

\subsection{Pedagogical Content Knowledge and Teacher Language Awareness}

Shulman (1986) looks at Pedagogical Content Knowledge as knowledge that "goes beyond knowledge of subject matter per se to the dimension of subject matter knowledge for teaching" (p. 9). He argues that this knowledge includes the most regularly taught topics in one's subject area, the most useful forms of representation of those ideas, the most powerful analogies, illustrations, examples, explanations, and demonstrations-in other words, the ways of representing and formulating the subject that make it comprehensible to others; and an understanding of what makes the learning of specific topics easy or difficult: the conceptions and preconceptions that students of different ages and backgrounds bring with them to the learning of those most frequently taught topics and lessons. That is, PCK represents "the blending of content and pedagogy into an understanding of how particular topics, problems, or issues are organised, represented and adopted to the diverse interests and ability of learners and presented for instruction" (Shulman, 1987: p. 8).

PCK concerns the manner in which teachers relate their pedagogical knowledge (what they know about teaching) to their subject matter knowledge (what they know about what they teach) in the school context for the teaching of specific students (Cochran, King, \& DeRuiter, 1993; Brophy, 1991 in Andrews, 2007; Van Driel \& Berry, 2010). Konig et al. (2016) looks at PCK as subject specific knowledge for the purpose of teaching. That is, teacher knowledge of the curriculum, knowledge of learners and knowledge of teaching strategies and multiple representation. This is the kind of knowledge that will separate a linguist from a teacher of English. This shows that a teacher of English needs to understand English as a language, its structure, use and acquisition; needs to understand the different methodologies that can be used to teach English; needs to understand learners he or she is teaching and the context in which they are learning English. It is, therefore, the role of the English teacher education programmes to produce this kind of teacher. 
Van Driel and Berry (2010) looks at PCK as specific form of knowledge for teaching which refers to the transformation of subject matter knowledge in the context of facilitating student understanding. That is, it implies a transformation of subject matter knowledge so that it can be used effectively and flexibly in the communication process between teachers and learners during classroom practice. According to Cochran, King and DeRuiter (1993), teachers' transformation of subject matter knowledge occurs in the context of two other important components of teacher knowledge which differentiates teachers form subject matter experts. One is teacher's knowledge of students including their abilities and learning strategies, ages and developmental levels, attitudes, motivations and their prior knowledge of the concepts to be taught. The other component is teacher understanding of social, political, cultural and physical environment in which students are asked to learn.

Andrews (2007) model of PCK is an adaptation of Shulman's (1987) model. Shulman (1986) proposed three major categories of knowledge: the subject matter content knowledge, pedagogical content knowledge and curricular knowledge, as earlier discussed. The categories were later extended to seven (Shulman, 1987) and these include: content knowledge, general pedagogical knowledge, curricular knowledge, pedagogical content knowledge, knowledge of learners, knowledge of educational contexts and knowledge of educational ends, purpose and values and their philosophical and historical grounds.

Andrews (2007) model of PCK maintains the five out of seven categories of Shulman, namely: content knowledge, general pedagogical knowledge, curricular knowledge, knowledge of learners, and knowledge of educational contexts. Instead of looking at Pedagogical Content Knowledge as a standalone category of knowledge, Andrews looks at it as an overarching category of knowledge that contains a number of categories of knowledge within it. This description of Pedagogical Content Knowledge by Andrews is in tandem with the description of PCK as discussed in this study. The other departure from Shulman's model is the knowledge of educational end, purpose and values which Andrews has not presented as a category of knowledge. One would argue that when one gains the knowledge of educational context and curricular knowledge one should be able to understand the purpose as well as the values of education. This could be the reason Andrews did not include it on the list.

The knowledge of content as discussed in TLA and KAL reflects the teachers' knowledge of the language (strategic competence and Language competence) and teachers' knowledge about the language (subject matter cognition). As discussed earlier on, a teacher who is knowledgeable about the language does not only understand how language operates but also the kind of struggle the learners face when learning the language (Wright, 2002). This idea is reflected in the component of knowledge of learners. In this model therefore, the PCK is seen as the overarching knowledge base and TLA is seen as subset of the teachers knowledge base (a knowledge base subset that is unique to the L2 teacher), which in- 
teracts with others and blends them in acts of expert L2 teaching (Andrews, 2007).

The literature clearly describes what the teacher education programme should have. It describes the kind of knowledge base the student teachers of second language should have by the end of their training. What might differ would be the packaging of the courses. The knowledge base for language teacher education programmes, as discussed in the review, are presented as separate entities that are needed in the programme. This paper, therefore, the idea was to analyse how these different aspects of the teacher education programmes are integrated in the Bachelor of Education (Language) Degree of Mzuzu University.

\section{Data Generation and Analysis}

Data was generated through document review. The curriculum document for Bachelor of Education (Language) was analysed. Other supporting documents like the TP Handbook and the student's handbook were also looked at in order to get more information related to the curriculum. The following are the documents that were analysed:

1) Mzuzu University Teaching Practicum Handbook (2017)

2) Mzuzu University Student Handbook (2010)

3) Bachelor of Education (Language) Curriculum Document (2016)

\section{Research Findings and Discussion}

\subsection{Description of the Programme}

The programme has four components: Content of the subject matter, Education foundation courses, Teaching Methodologies and Teaching Practice. Each student is expected to go through these in order to graduate with a Bachelor of Education (Language). Each student in levels 1 and 2 is expected to take 5 units. In the case of English, the student will have half a unit of literature and half a unit of linguistics. A Unit means "a measure of the amount of effort required for course work, and will mean a course (or combination of courses) that 1) is reported as a single item for Semester end assessment and 2) comprises 4 to 6 contact hours per week throughout the 16 weeks Semester" (Mzuzu University Student Handbook, 2010: p. 8). In levels 3 and 4, each student is expected to take 6 units and out of the six, two are for English one unit for literature and one unit for linguistics. For the English methodology course, the student takes about 2 units because each English methodology course is half a unit as it is combined with a methodology course of the other teaching subject.

The language teacher education programme seems to have many content courses as opposed to the teaching methodology courses. In terms of units, it seems student teachers of English will do 14 units of English both Language and Literature, 8 units of Education foundations and then do 3 units of English teaching methodology before they graduate. The implication of this is that the teacher trainers will have challenges as regards to exposing students to the prac- 
tical aspect of the profession before they actually go for TP.

\subsection{Subject Content Knowledge Included in Language Teacher Education Programme}

The study sought to analyse the subject content knowledge that is embedded in the programme. The following are the content courses in the programme:

\begin{tabular}{|c|c|c|}
\hline Level & Semester & Course name \\
\hline 1 & 1 & $\begin{array}{l}\text { Introduction to Literature } \\
\text { Introduction to Language }\end{array}$ \\
\hline 1 & 2 & $\begin{array}{l}\text { Trends in African Literature } \\
\text { Introduction to Phonetics and Phonology }\end{array}$ \\
\hline 2 & 3 & $\begin{array}{l}\text { MalawianLiterature } \\
\text { Sociolinguistics }\end{array}$ \\
\hline & 4 & $\begin{array}{l}\text { Theory and Practice of Drama } \\
\text { Discourse Grammar }\end{array}$ \\
\hline 3 & 5 & $\begin{array}{l}\text { Literary Theory and Criticism } \\
\text { Meaning in Language }\end{array}$ \\
\hline & 6 & $\begin{array}{l}\text { Shakespeare } \\
\text { Language Acquisition \& Learning }\end{array}$ \\
\hline 4 & 7 & $\begin{array}{l}\text { Creative Writing } \\
\text { English Syntax }\end{array}$ \\
\hline & 8 & $\begin{array}{l}\text { Trends in European Literature } \\
\text { Language and Gender }\end{array}$ \\
\hline
\end{tabular}

The content of the subject matter is in two, literature and linguistics. The courses in both pure and applied linguistics give students a chance to understand the structure and use of language which might make it easier to teach English in secondary schools. The provision of linguistic courses in the programmes agrees with Wright (2002), Attardo and Brown (2005), Bartels (2005) and Andrews (2007) who agree on the importance of linguistics in a language teacher education programme. The courses will give the students an edge to handle language in schools. It should also be noted that most of these courses are closely related to the areas that are taught in secondary schools. The student teachers might not teach this content in the classroom but might use the information to understand the structure of language as well as the analysis of literature.

\subsection{Pedagogical Knowledge Embedded in the Language Teacher Education Programme}

The study also sought to analyse the pedagogical knowledge embedded in the language teacher education. There are two courses that are offered in regards to pedagogical knowledge: Education Foundations and English Teaching Methods. The Education Foundation courses are general in nature; they focus on the 
school, the classroom and the pupil in general. The English teaching methodology are specific to the teaching of English.

\subsubsection{Education Foundations}

The following are the courses that are offered in Education Foundations:

\begin{tabular}{|c|c|c|}
\hline Level & Semester & Course name \\
\hline \multirow{4}{*}{2} & \multirow{2}{*}{3} & Philosophy of Education \\
\hline & & Educational Psychology \\
\hline & \multirow{2}{*}{4} & General Teaching Methods \\
\hline & & Testing, Measurement and Evaluation \\
\hline \multirow{4}{*}{3} & \multirow{2}{*}{5} & Instructional Media and Technology \\
\hline & & Curriculum Theory and Practice \\
\hline & \multirow{2}{*}{6} & Sociology of Education \\
\hline & & Educational Research Methods \\
\hline \multirow{5}{*}{4} & \multirow{3}{*}{7} & Introduction to Inclusive \\
\hline & & Education \\
\hline & & Adolescent Psychology \\
\hline & \multirow{2}{*}{8} & Guidance and Counselling \\
\hline & & Leadership and Management \\
\hline
\end{tabular}

The students are introduced to the Education Foundation courses in year 2. All the courses that are offered are half units. It can be observed that the Education foundations courses provide students with an understanding of what education is all about. It provides information about the school, general teaching methods, leadership, the learner and the curriculum. Shulman, 1986, 1987; Cochran, King, and DeRuiter (1993); Lowernberg-Ball, Thames and Phelps (2008); Van Driel and Berry (2010) and Konig et al., 2016 agree that a teacher needs to have pedagogical content knowledge and this knowledge will include understanding of the school context as well as the nature of students they teach that is apart from knowledge of the content and the pedagogy. This is the kind of knowledge that Education foundation courses offer to the students.

\subsubsection{English Teaching Methodology}

The students are exposed to teaching methodologies at year 3 . The following are the courses offered:

\begin{tabular}{ccl}
\hline Level & Semester & \multicolumn{1}{c}{ Course } \\
\hline 3 & $1(5)$ & $\begin{array}{l}\text { Theories and Approaches to Language teaching (full } \\
\text { course) } \\
\text { Classroom practice in English (half course) } \\
\end{array}$ \\
$2(6)$ & $1(7)$ & Classroom Observation and Analysis (full course) \\
& $2(8)$ & Innovative and Evaluative Teaching Method (half course) \\
\hline
\end{tabular}


Darling-Hammond (2006), Richards (2008), Johnson (2009), Graves (2009), and Freeman (2009) indicate that apart from content, courses in pedagogies (methodologies) are part the language teacher education. However, they do not say how much content on pedagogy is needed. As observed earlier it seems the programme has more content courses than the methodology courses and this might be a challenge. One might argue that the number of courses might not really matter but the quality of the courses.

The Methodology courses, in the programme have tried to provide space and time for the students to get familiarised with the teaching process and also practise teaching. For example, the English teaching methodology course in level 3 semester 6 Classroom Practice in English has its aim as to Familiarise student with various approaches and methods of teaching the four language skills, grammar and literature in secondary schools. The course outline also indicates that by the end of the course the learners should be able to: Interpret the English syllabus; Organise teacher/learner tasks for a literature and language class; Design schemes of work and lesson plans; Teach lessons in English language and literature; and Prepare assessment tools for language skills, literature and grammar. The course has peer teaching as an activity or topic in the course. The course has been designed in such a way that if this is implemented the way it should then the students will be equipped with practical skills in the teaching of English. The course has made deliberate effort expose students to the teaching process before they actually go into the schools. The question of course, is how far do the facilitators implement it the way it is supposed to?

Another example is the methodology course in level 4 semester 7, Classroom Observation and Analysis whose aim is to equip students with skills of observing and evaluating lessons in language and literature. According to the course, by the end of the course, the learners are expected to follow proper procedures of observing a lesson; demonstrate understanding of the patterns of classroom interaction; and analysing a lesson by utilising actual classroom data. The assessment of this course is $100 \%$ practical work. The assumption one gets from this course is that when students observe how other teachers or peers are teaching, they might appreciate and understand the realities of the classroom and learn from those that have been in service for some time. This might help them to see how the knowledge they have gained in the lecture rooms of the university fits in or does not fit in with the real classroom situation.

The programme has also tried to integrate the subject content with the methodology courses. For example, the Language teaching methodology course in level 3 semester 5, Theories and Approaches to Language Teaching whose aim is to examine the different theories that have influenced language teaching methods and to familiarise the students with various approaches to language teaching. The content of the course include: Basic concepts in language learning; Theories of language; Theories of language learning; and Approaches to language teaching. The basic concepts and the theories that are taught in this course 
are concepts and theories from linguistic courses like Introduction to language, Sociolinguistics, Discourse grammar, and Language Acquisition and Learning. This kind of link might help the students not to view linguistics as a separate entity; not connected to the process of teaching and learning, but a course that has direct link to the methodology course. That is, they will learn to understand that methodology courses aim to help them deliver or use the content that they learn in the content courses. This seems to agree with the observation by Van Driel and Berry (2010) that a teachers knowledge which is PCK is and inter play of subject matter and teaching and learning and context and how these are combined and used to when teaching.

\subsection{Actualisation of Theory and Practice in the Programme}

Teaching practice at the institution is a school term long. Generally, in Malawi a school term runs between 12 - 14 weeks. The school term will indeed give them the kind of experience that is expected as there are many activities that happen in a school, in a term. The students are sent to the schools at the beginning of the term and they leave the schools after the close of the term. The TP is done between semester 7 and 8 in other words in between first semester and second semester of year 4. After TP, the students are exposed to another methodology course called Innovative and Evaluative teaching methods. The aim of the course is to discuss student's experiences in the teaching of English Language and Literature and to enable students choose alternative methods which they would have used to teach English Language and Literature. This course gives a chance to the facilitators to get feedback from the students on their experiences and for the facilitators to work on the challenges which the students face during TP. As the aim suggests, the student teachers have a chance to evaluate their own lessons and try to come up with innovative ways of teaching the same content which they taught during TP.

According to the institutions Mzuzu University Teaching Practicum Handbook (2017), the aims of the TP is to ensure the meaningful translation of theory into practice; to prepare a competent, effective and efficient school instructor; and to promote ongoing professional development and induction in the teaching profession. The specific objectives of the TP include among others: student teachers being able to plan and prepare schemes and records of work; plan and prepare individual lessons for effective teaching and learning; present individual lessons competently and confidently; and use the chalk and other teaching/learning resources effectively. These objectives seem to relate to the objectives for the methodology course in level 3 semester 6 discussed above. This shows that TP is important in the teacher education programme as it gives the student teachers a chance to learn how to teach and to understand what being a teacher is. Their school and classroom experiences are very important in the process of becoming a teacher (Graves, 2009; Glenn, 2006; Caires \& Almedia, 2007; Cabaroglu, 2014; Konig et al., 2016). 
TP at the institution seems to be highly valued as a practical component of teacher education in that its grade is a standalone grade, and it contributes $100 \%$ at the end of the programme. The classification of the Degree takes into account the TP component. For example, for a student to get a pass, he or she needs to get: "A minimum mean mark of $45 \%$ in Level 3 and Level 4 courses, a mark of at least $50 \%$ in Teaching Practicum and a mark of $45 \%$ in Research Project" (Mzuzu University Student Handbook, 2010).

The classification of the Degree puts TP grade at par with the other theoretical courses i.e. the content, educational foundations and the methodology courses, however, TP has a higher pass mark than the other components. The pass mark for TP is $50 \%$ whilst the other components the pass mark is $45 \%$. This means TP is a critical aspect as far as this programme is concerned. The assumption is, if the student gets $50 \%+$ then he or she is able to use or transfer the skills learnt from the university in the situation of a real classroom, and he or she now fits into the world of teachers.

\subsection{The Pedagogical Content Knowledge that in Embedded in the Language Teacher Education Programme}

Van Driel and Berry (2010) view the development of PCK as a complex interplay between knowledge of subject matter, teaching and learning and context and the way the teachers combine and use this knowledge to express their expertise. Therefore, looking at the teacher education programmes, one sees: the interplay of the content that needs to be taught in the secondary schools; the methods and strategies to use in order to teach such content; the context in which these teachers will teach; the learners that these teachers will teach; and the use of this knowledge through practice.

The teacher education programme under study has all the necessary courses to help students acquire the different categories of PCK according to Andrews (2007). What is missing in the programme are courses that would help the student teachers to work on their strategic and language competence. Andrews $(2003,2001)$ argues that teachers of English need to have knowledge of language (content knowledge) and Knowledge about language (language proficiency). It has been noted that apart from the general communication studies courses that are offered to all students at the University in year 1 there is no other course that would help the would-be teachers of English to develop their strategic and language competence. One might argue that the Linguistics courses, would help student teachers develop strategic and language competence. However, going through the course outlines one notices that the idea is to help the student teachers understand the language that they will teach, not necessarily for them to learn to communicate using the language.

The emphasis on Strategic and Language competence is in line with Kelly et al.'s (2004) observation that a Language Teacher Education programme should include training in the development of independent language learning strategies. They indicate that student teachers should develop independent language learn- 
ing strategies to improve their language competence and be able to transfer these skills to their own learners. The importance of competence in the language of instruction can never be overemphasised. A teacher needs to be competent in the language of instruction if he or she is to make teaching effective. This omission in the teacher education programmes could be based on the assumption that by year one at the University or college they have mastered enough English to use for teaching.

The emphasis of Andrew's model of PCK is on TLA. The findings of the study indicate that for a student teacher to have TLA he or she needs a combination of courses which include linguistics, English Grammar, Literature, English teaching methods as well as Education foundations. The theoretical knowledge gained in the lecture room is actualised in the teaching practice. The TP gives students to put into practice what they learnt in the lecture room. This is in terms of content and how this content can be delivered to learners of second language. The study clearly shows that there is a connection between and among the courses in the programme despite the fact that they are offered from different departments.

\section{Conclusion}

The Bachelor of Education (Language) programme has made an effort to integrate theory and practice. The programme equips student teachers with the necessary pedagogical content knowledge to survive in the secondary school classroom. Pedagogical content knowledge being the special knowledge that a teacher of English needs to have is very crucial in becoming a teacher. If the curriculum is implemented the way it is supposed to then for sure the teacher that comes out of the programme will have no challenges to survive in the real classroom.

There is a need however, to make sure that there is a balance in the number of courses that are offered to the students in each strand of the programme. The teaching methodology courses for example are courses that bring the content and the general issues in education together. This is the course that equips student teachers with PCK as such these courses need to be given more attention. There is a need to have more courses in methodology. The fact that content is important can never be overemphasised but there is too much concentration of content in the programme. The progamme is leaning more towards content than what it needs to focus on, that is, the training of teachers.

\section{Conflicts of Interest}

The author declares no conflicts of interest regarding the publication of this paper.

\section{References}

Andrews, S. (2001). The Language Awareness of the L2 Teacher: Its Impact Upon Pedagogical Practice. Language Awareness, 10, 75-90. https://doi.org/10.1080/09658410108667027

Andrews, S. (2003). Teacher Language Awareness and the Professional Knowledge Base 
of the L2 Teacher. Language Awareness, 12, 81-95.

https://doi.org/10.1080/09658410308667068

Andrews, S. (2007). Teacher Language A wareness. Cambridge University Press. https://doi.org/10.1017/CBO9780511497643

Attardo, S., \& Brown, S. (2005). What's the Use of Linguistics? Pre-Service Teachers' Beliefs towards Language Use and Variation. In N. Bartel (Ed.), Applied Linguistics and Language Teacher Education (pp. 91-102). Springer. https://doi.org/10.1007/1-4020-2954-3_6

Bachelor of Education (Language) Curriculum Document (2016). Mzuzu University.

Bartels, N. (2005). Applied Linguistics and Language Teacher Education: What We Know. In N. Bartel (Ed.), Applied Linguistics and Language Teacher Education (pp. 405-425). Springer. https://doi.org/10.1007/1-4020-2954-3_23

Beytekin, O., \& Chipala, H. (2015). The Quality Standardisation of Teachers in Malawi Government Secondary Schools. British Journal of Education, Society and Behavioural Science, 11, 1-9. https://doi.org/10.9734/BJESBS/2015/18207

Cabaroglu, N. (2014). Re-Visiting the Theory and Practice Gap through the Lens of Student Teacher Dilemmas. Australian Journal of Teacher Education, 39, 88-109. https://doi.org/10.14221/ajte.2014v39n2.10

Caires, S., \& Almeida, L. (2007). Positive Aspects of the Teacher Training Supervision: The Student Teachers' Perspective. European Journal of Psychology of Education, 22, Article No. 515. https://doi.org/10.1007/BF03173469

Cochran, K., King, R., \& DeRuiter, J. (1993). Pedagogical Content Knowledge: A Tentative for Teacher preparation. Journal of Teacher Education, 44, 263-277. https://doi.org/10.1177/0022487193044004004

Darling-Hammond, L. (2006). Constructing 21st Century Teacher Education. Journal of Teacher Education, 57, 300-314. https://doi.org/10.1177/0022487105285962

Freeman, D. (2009). The Scope of Second Language Teacher Education. In A. Burns, \& J. C. Richards (Eds.), Cambridge Guide to Second Language Teacher Education (pp. 11-19). Cambridge University Press.

Glenn, W. (2006). Model versus Mentor: Defining the Necessary Qualities of the Effective Cooperating Teacher. Teacher Education Quarterly, 33, 85-95.

Graves, K. (2009). The Curriculum of Second Language Teacher Education. In A. Burns, \& J. C. Richards (Eds.), Second Language Teacher Education (pp. 115-124). Cambridge Press.

Johnson, K. E. (2009). Trends in Second Language Teacher Education. In A. Burns \& J. C. Richards (Eds.), Cambridge Guide to Second Language Teacher Education (pp. 20-29). Cambridge University Press.

Kelly, M., Grenfell, M., Allan, R., Kriza, C., \& McEvoy, W. (2004). European Profile for Language Teacher Education: A Frame of Reference. University of Southampton. http://www.researchgate.net

Konig, J., Lammerding, S., Nold, G., Rohde, A., Strauß, S., \& Tachtsoglou, S. (2016). Teachers' Professional Knowledge for Teaching English as Foreign Language: Assessing the Outcomes of Teacher Education. Journal of Teacher Education, 67, 320-337. https://doi.org/10.1177/0022487116644956

Lowenbrg-Ball, D., Thames, M., \& Phelps, G. (2008). Content Knowledge for Teaching: What Makes It Special. Journal of Teacher Education, 59, 389-407.

https://doi.org/10.1177/0022487108324554

Lowernberg Ball, D. (2000). Bridging Practices: Intertwining Content and Pedagogy in 
Teaching and Learning to Teach. Journal of Teacher Education, 51, 241-247. https://doi.org/10.1177/0022487100051003013

Mzuzu University Student Handbook (2010).

Mzuzu University Teaching Practicum Handbook (2017).

Richards, J. (2008). Second Language Teacher Education Today. Regional Language Centre Journal, 39, 158-177. https://doi.org/10.1177/0033688208092182

Schulz, R. (2000). Foreign Language Teacher Development: MLJ-Perspective 1916-1919. The Modern Language Journal, 84, 495-522. https://doi.org/10.1111/0026-7902.00084

Shulman, L. (1986). Those Who Understand: Knowledge Growth in Teaching. Educational Traditions, 15, 4-14. https://doi.org/10.3102/0013189X015002004 http://www.jstor.org/stable/1175860

Shulman, L. S. (1987). Knowledge and Teaching: Foundations of the New Reform. Harvard Educational Reviews, 57, 1-21.

https://doi.org/10.17763/haer.57.1.j463w79r56455411

Van Driel, J. H., \& Berry, A. (2010). Pedagogical Content Knowledge. In P. Peterson, E. Baker, \& B. McGaw (Eds.), Encyclopedia of Education (pp. 656-661). Elsevier. https://doi.org/10.1016/B978-0-08-044894-7.00642-4

Wright, T. (2002). Doing Language Awareness: Issues for Language Study in Language Teacher Education. In H. Trappes-Lomax \& G. Ferguson (Eds.), Language in Language Teacher Education (Vol. 4, pp. 113-130). John Benjamins. https://doi.org/10.1075/1llt.4.09wri 